\title{
Haematological and Biochemical Responses of Juvenile Malabar Blood Snapper (Lutjanus malabaricus Bloch \& Schneider, 1801) Exposed to Different Rearing Temperatures and Diets
}

(Tindak Balas Hematologi dan Biokimia Ikan Merah Juvenil Tanda Hitam (Lutjanus malabaricus Bloch \& Schneider, 1801) Terdedah kepada Suhu dan Diet Penternakan Berbeza)

\author{
SABuj Kanti MaZumder, Sveinung Fivelstad, MAZlan AbD. GHAFFAR \& Simon Kumar Das*
}

\section{ABSTRACT}

This study is conducted to examine the impacts of different rearing temperature and diet variation on haematological and serum biochemical parameters on the juvenile Lutjanus malabaricus, a commercially important fish species in Malaysia. Fish (16-18 cm) were divided into eight treatments (4 temperatures $\times 2$ diets) each with three replicates of five juveniles each. Fish were subjected to four different rearing temperatures $\left(22,26,30\right.$ and $\left.34^{\circ} \mathrm{C}\right)$ and fed with a commercial pellet and a natural shrimp diet. After 30 days of experimental period, blood samples were collected and transferred into two different tubes from each sample: One containing EDTA as an anticoagulant agent and the other without EDTA for serum collection. All the haematological and biochemical parameters in all the treatments were within the normal range. Changing temperature and diet led to a significant change $(\mathrm{p}<0.05)$ in the total length $(T L)$, body weight $(B W)$, red blood cell (RBC), haemoglobin (HB), haematocrit (HC), thrombocyte (TC) and white blood cell (WBC) but the change in mean corpuscular volume $(\mathrm{MCV})$, mean cell haemoglobin $(\mathrm{MCH})$ while mean cell haemoglobin concentration $(\mathrm{MCHC})$ were not significant $(\mathrm{p}>0.05)$. The fish reared at $26^{\circ} \mathrm{C}$ and $30^{\circ} \mathrm{C}$ had significantly higher values than those reared at $22^{\circ} \mathrm{C}$ and $34^{\circ} \mathrm{C}(\mathrm{p}<0.05)$. Total protein $(T P)$, albumin $(A L B)$, albumin/globin ration $(A / G$ ratio $)$, alkaline phosphatase $(A P)$, aspartate aminotransferase (AST) and alanine transaminase $(A L T)$ level were also significantly increased at $30^{\circ} \mathrm{C}$ and $26^{\circ} \mathrm{C}$ compared to that of $34^{\circ} \mathrm{C}$ and $22^{\circ} \mathrm{C}$. Globulin (GLB) level showed the opposite trend. In all the cases the performances were higher in shrimp diet than pellet diet. It is suggested that these physiological parameters can be conveniently employed as health monitoring tools in fish culture practices.

Keywords: Diet; fish; haematology; serum biochemistry; temperature

\section{ABSTRAK}

Kajian ini dijalankan bagi meneliti impak perbezaan suhu dan variasi diet pada parameter hematologi dan serum biokimia pada juvenil Lutjanus malabaricus, satu spesies ikan komersial penting di Malaysia. Ikan (16-18 cm) dibahagikan kepada lapan rawatan (4 suhu $\times 2$ diet) dan terdapat tiga replikat (5 ikan setiap replikat) bagi setiap rawatan. Ikan terdedah kepada empat suhu yang berbeza $\left(22,26,30\right.$ dan $\left.34^{\circ} \mathrm{C}\right)$ dan diberi makan pelet komersial dan diet udang semula jadi. Selepas 30 hari tempoh uji kaji, sampel darah diambil dan dipindahkan ke dalam dua tiub yang berbeza daripada setiap sampel: satu yang mengandungi EDTA sebagai agen antikoagulan dan yang lain tanpa EDTA untuk pengumpulan serum. Semua parameter hematologi dan biokimia dalam semua rawatan berada dalam julat normal. Perubahan suhu dan diet menyebabkan perubahan ketara $(\mathrm{p}<0.05)$ dalam jumlah panjang $(T L)$, berat badan (BW), sel darah merah (RBC), hemoglobin (HB), hematokrit (HC), trombosit (TC) dan sel darah putih (WBC) tetapi perubahan jumlah min korpuskul $(\mathrm{MCV})$, min sel hemoglobin (MCH), manakala nilai min kepekatan sel hemoglobin (MCHC) tidak signifikan (p >0.05). Nilai yang lebih tinggi dilihat pada ikan yang diternak pada 26 dan $30^{\circ} \mathrm{C}$ daripada yang diternak pada 22 dan $34^{\circ} \mathrm{C}(\mathrm{p}$ $<0.05)$. Jumlah protein (TP), albumin (ALB), nisbah albumin/globin (nisbah A/G), alkali fosfatase (AP), tahap aspartat aminotransferase (AST) dan alanine transaminase (ALT) juga meningkat dengan ketara pada $30^{\circ} \mathrm{C}$ dan $26^{\circ} \mathrm{C}$ berbanding dengan $34^{\circ} \mathrm{C}$ dan $22^{\circ} \mathrm{C}$. Tahap Globulin (GLB) menunjukkan keputusan yang bertentangan. Dalam semua kes, prestasi juvenil lebih tinggi apabila diternak menggunakan diet udang berbanding diet pelet. Parameter fisiologi yang digunakan dalam kajian ini telah dicadangkan sebagai pemantau kesihatan yang mudah dalam penternakan ikan.

Kata kunci: Diet; hematologi; ikan; serum biokimia; suhu

\section{INTRODUCTION}

Aquaculture plays an important role in global efforts towards eliminating human hunger and malnutrition by supplying fish and other aquatic products rich in protein, essential fatty acids, vitamins and minerals. To achieve good growth in aquaculture, fish must be healthy, well 
fed, resistant to diseases and handling and the water must be of the required quality (Fazio et al. 2013). Haematological and biochemical parameters are among the most important indicators of fish health (Maceda-Veiga et al. 2010) and changes in the proportion of blood cells may be indicative of a disease or an exposure to chemicals (Elahee \& Bhagwant 2007; Gunben et al. 2014). These parameters are closely related to the response of the animal to the environment, an indication that the environment where fish lives could exert some influence on the blood characteristics (Fernandes \& Mazon 2003). As well as haematological parameters, also the determination of protein content in blood plasma is a good indicator to detect intra- and inter-specific variation among species, identify populations, and for investigation of ecological stress, physiological homeostasis and aquatic pollution (SharafEl-Deen \& Abdel-Hamid 2002). Serum proteins are very complex and are involved in a wide range of physiological functions in both healthy and disease states, which is why they play a role of great importance for zoologists, enzymologists, immunologists and toxicologists. Since physiological and biochemical characteristics of fish blood are easily modified by environmental changes, these parameters can be useful as biomarkers of different aquatic habitat of fish, too (Atamanalp et al. 2002). Fish live in very intimate contact with their environment, and are therefore very susceptible to physical and chemical changes which may be reflected in their blood components (Wilson \& Taylor 1993).

A multitude of intrinsic and extrinsic factors cause normal and abnormal variations in haematologic and biometric data such as species and strain, temperature, stress, food, the cycle of sexual maturity, health condition and water quality (Vázquez \& Guerrero 2007). Among the factors, temperature has a profound effect on chemical and biological processes (Mazumder et al. 2014). Temperature of aquatic environment is important for ensuring survival, distribution and normal metabolism of fish, failure to adapt to temperature fluctuations is generally ascribed to the inability of fish to respond physiologically with resultant mortality, which is related to changes in the metabolic pathways (Forghally et al. 1973). The result is a collapse in osmoregulatory functions during temperature extremes (Gubbins et al. 2000; Rahman et al. 2017). Fish can adapt to the changed temperature of its habitat to a certain extent, but when a particular temperature exceeds the threshold value, thermal stress occurs. The temperature at which stress begins to occur is largely dependent on a fish's prior experience or acclimation (Barton 2002). In fish, thermal acclimation is generally determined by blood parameters changes, during which an initial period of thermal stress is followed by a gradual compensation. When a stable blood parameters level that is consistent between the old and new thermal state is reached, the animal is considered to be fully acclimated (Maricondi-Massari et al. 1998).

Beside temperature, haematological and biochemical parameters are also reported to be affected by dietary (Ferguson et al. 2010). In fish culture, nutrition obviously plays an important role in the maintenance of a healthy and marketable product. On a commercial scale, fish are fed formulated diets, but in the wild the fish has a diverse diet comprising numerous organisms including shrimp, copepods, polychaetes, amphipods, macrophagous detritus, gastropods, bivalves, barnacles and crabs (Wassef \& Eisawy 1985). Growth prediction, which is crucial for planning of fish production, requires information about feed intake since growth increases with increasing ration. Under aquaculture feeding, feed intake prediction still remains a great challenge (Pauly 1995). A number of studies have shown that differences in blood cell formation and function can also be indicative of dietary manipulations (Duncan et al. 1993; Wise et al. 1993). Effective management practice has been recognized as a key to profitable and sustainable fish farming. This has led to the application of appropriate feeding strategies to maximize fish production in the culture environment (Akinrotimi et al. 2007).

Among the several species of marine fish, one that stands out is the Malabar blood snapper (L. malabaricus Bloch \& Schneider, 1801), for its commercial interest, economic importance and extensive consumption as food source. This species shows many biological aspects that are favourable for aquaculture: it is a euryhaline fish, has extroverted habits and it is tolerant to high densities, therefore, it is one of the major tropical species produced by the aquaculture industry. The development of culture techniques suitable for this species has been on-going for many years in countries such as Malaysia, Thailand, Australia and Canada (Rosenlund \& Skretting 2006; Treasurer et al. 2006). However, questions on the metabolic traits of the species and its ability to cope with environmental stressors have received little attention. Moreover, data on the normal haematological and biochemical blood parameters of the L. malabaricus, and the effect of temperature, and diet differences do not exist, not only in Malaysia but also the other part of the world.

Therefore, there is a need to observe the effect of different rearing temperature and diet of this commercially important fish species. Thus, the effects of four different temperatures fed with two different commercial pellets and a natural shrimp diet was studied, to investigate the ability of this species to cope with temperature stress and availability of two different foods. The present study will form baseline data for assessment of health status of L. malabaricus as well as reference point for future comparative studies of different temperature and food preferences of commercially important fish species.

\section{MATERIALS AND METHODS}

\section{SAMPLING AND EXPERIMENTAL SETUP}

A homogeneous group (length: $21.24 \pm 2.01 \mathrm{~cm}$, weight: $167.44 \pm 23.98 \mathrm{~g}$ ) of L. malabaricus collected from local hatcheries of Pulau Ketam ( $03^{\circ} 01^{\prime} 20^{\prime \prime} \mathrm{N}$ and $101^{\circ} 15^{\prime}$ 20" E), Selangor, peninsular Malaysia and transported to 
the marine science laboratory of UKM Bangi, Malaysia (Figure 1).

The fish were housed in stocking tanks with equal dimensions $(1.96 \mathrm{~m} \times 1.02 \mathrm{~m} \times 0.61 \mathrm{~m}, 1200 \mathrm{~L})$ for up to 7 days with a sustained environmental temperature $\left(\sim 26^{\circ} \mathrm{C}\right)$ and salinity (30 psu) and a diet consisting of formulated pellets (protein: $45-47 \%$, lipid: $8 \%$, and carbohydrate: $7 \%$ ). Once the fish started feeding and excreting wastes, they were transferred to 24 experimental tanks where the experiment was carried out for a period of 30 days. The tanks have equal dimensions $(1.2 \mathrm{~m} \times 0.5 \mathrm{~m} \times 0.58 \mathrm{~m}, 400 \mathrm{~L})$.

Tanks were randomly divided into eight treatments (four temperatures $\times$ two diets). At four different temperatures, twelve tanks were subjected to pellet diet, and the other twelve tanks were subjected to shrimp diet. Under each temperature condition, three replicates were used. Each experimental tank contained five fish. The fish were manually fed with a commercial diet pellet (protein:
45-47\%, lipid: $8 \%$, and carbohydrate: $7 \%$ ) or natural shrimp diet (Acetes sp.; protein: $57.55 \%$, lipid: $7.56 \%$, and carbohydrate: $7.54 \%)$ twice a day $(09.00$ and 16.00 h) until apparent satiation was observed. Satiation was determined as the point when fish stopped feeding actively and feeds settled at the bottom of the tanks for more than 2 min. Leftover food was collected, dried, and weighed (the weight of dried left over food was about $71 \%$ of the wet food); and the total consumption was determined accordingly (De et al. 2016).

The temperature changes for the experimental groups were increased at a rate of $2^{\circ} \mathrm{C}_{\text {day }}^{-1}$ using a thermostat (E-JET heater $200 \mathrm{~W}$, Penang, Malaysia) and a chiller (HS-28 A, 250-1200L/H, Guangdong Hailea Grouph Co. Ltd.) until the experimental temperature that started at the minimum temperature of $22^{\circ} \mathrm{C}$ reached the maximum of $34^{\circ} \mathrm{C}\left(22,26,30\right.$, and $\left.34^{\circ} \mathrm{C}\right)$. The fish were then deprived of food for 2 days and anesthetized with $\alpha$-methyl quinoline

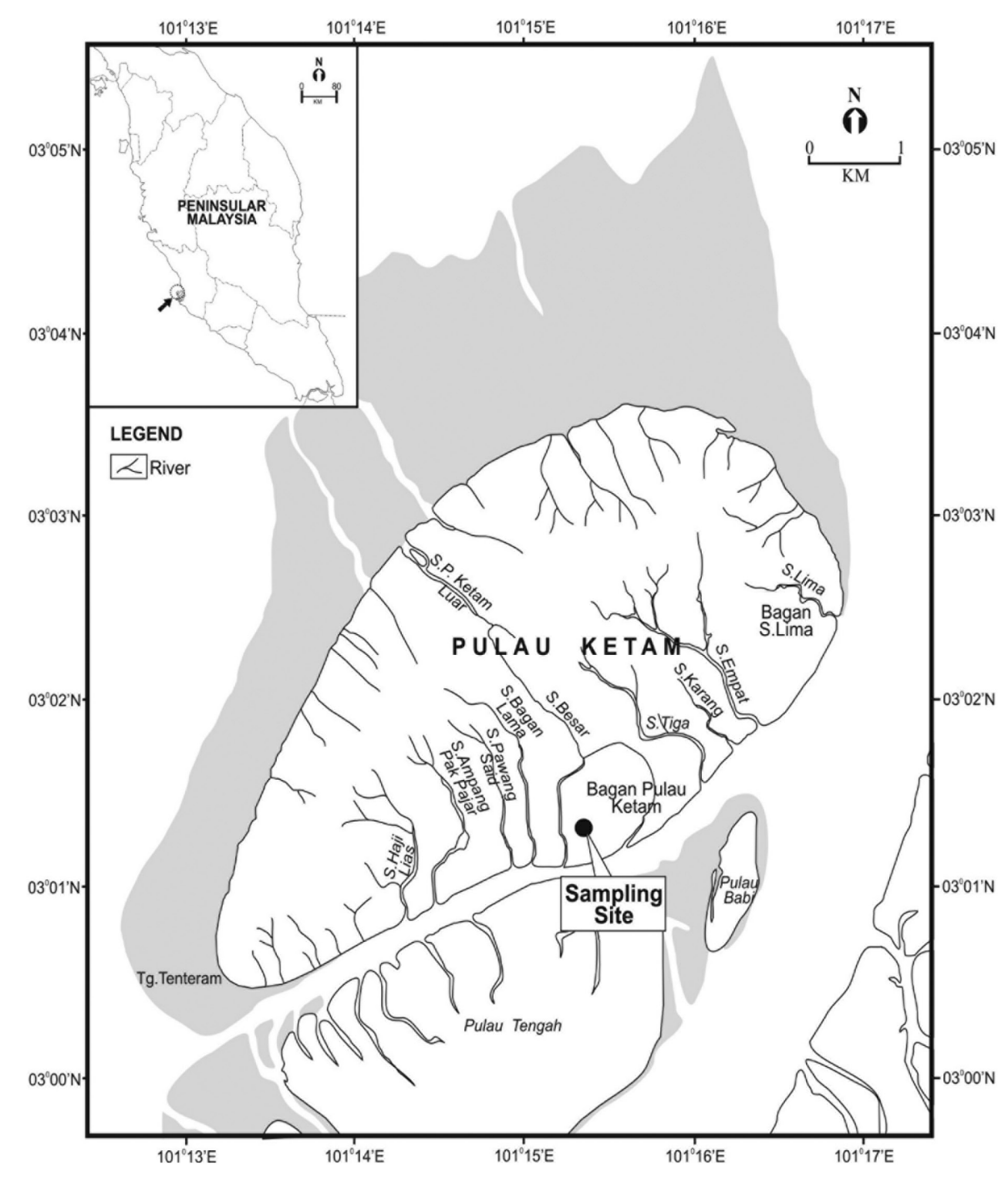

FIGURE 1. Map depicting location of hatchery Pulau Ketam, Selangor, Malaysia 
(Transmore $^{\mathrm{R}}$; Nika Trading, Puchong, Malaysia) (0.22 mL $\mathrm{L}^{-1}$ in $3 \mathrm{~L}$ of sea water as dan anasthetic medium for 10-15 min) (Das et al. 2018, 2014; Noor et al. 2018). The process of anaesthetization involved, first of all $3 \mathrm{~L}$ of sea water taken in a bowl and added $0.66 \mathrm{mg}$ of $\alpha$-methyl quinoline and stired vigorously for proper mixing. The fish were then placed into the bowl for anaesthetization until ventilatory movements ceased prior to the initial measurement of body weight $(\mathrm{g})$ and total length $(\mathrm{cm})$. The total length was measured to the nearest $0.1 \mathrm{~cm}$ with a measuring board and weighed to the nearest $0.01 \mathrm{~g}$ using an electronic balance (Model: KD-300KC) (Mazumder et al. 2018a, 2018b, 2016).

During the 30-day experimental period, the water quality parameters viz., temperature, salinity, and $\mathrm{pH}$ were monitored daily, whereas the total ammonia nitrogen $\left(\mathrm{NH}_{3}-\mathrm{N}\right)$ and total hardness were measured weekly. All measurements were taken at $0900 \mathrm{~h}$. Temperature, $\mathrm{pH}$, and salinity were monitored using a YSI 59 Multiparameter Water Quality Probe (Yellow Springs Instrument Company $\mathrm{OH}, \mathrm{USA}) . \mathrm{NH}_{3}-\mathrm{N}$ was measured using the salycilate method (Hach ${ }^{\mathrm{TM}}$ method 8155), and total hardness was measured by titration (La Motte Chemical test kit, model WAT-DR). During the experimental period, samples were maintained on a $12 \mathrm{~h}$ light: $12 \mathrm{~h}$ dark photoperiod.

\section{SURGICAL PROCEDURES AND BLOOD HAEMATOLOGY ANALYSIS}

At the end of the 30 days experiment period, fish were starved for $24 \mathrm{~h}$ and were anesthetized with $\alpha$-methyl quinoline (Transmore ${ }^{\circledR}$; Nika Trading, Puchong, Malaysia) ( $0.22 \mathrm{~mL} \mathrm{~L}^{-1}$ in $3 \mathrm{~L}$ of sea water as a anasthetic medium) until ventilatory movements ceased. The fish were then transferred to a surgery table, where oxygenated seawater containing $\alpha$-methyl quinoline $\left(0.22 \mathrm{~mL} \mathrm{~L}^{-1}\right)$ continuously irrigated their gills. The procedure used to implant the flow probe was modified from that described Gollock et al. (2006). Blood samples were collected from caudal vein of five fish (non-lethal sampling) from each experimental group using a sterile plastic syringe $(2.5 \mathrm{~mL})$ and transferred into 2 different tubes: one (Miniplast $3.0 \mathrm{~mL}$; LP Italiana Spa, Milano) containing ethylenediamine tetraacetic acid (EDTA, $1.26 \mathrm{mg} / 0.6 \mathrm{~mL}$ ) as an anticoagulant agent, and the other without EDTA for serum collection. The blood samples collected in EDTA tubes were used for determination of the haematological profile, which was measured within $1 \mathrm{~h}$ after blood samples were taken using an automated haematology analyzer (HeCo Vet C; SEAC, Florence, Italy) with special lysing reagent for fish (SEAC, Code 71010460), previously used to investigate haematological profile in other fish species (Fazio et al. 2013, 2012). Evaluation of the haemogram involved the determination of the red blood cell count (RBC), haemoglobin concentration (HB), haematocrit (HCT), mean corpuscular volume (MCV), mean corpuscular haemoglobin (MCH) and mean corpuscular haemoglobin concentration (MCHC), thrombocyte (TC) and white blood cell count (WBC). Animal experiments were approved by the Animal ethics committee of National University of Malaysia with the code FST/2016/SIMON/27-July/763-July2016-May-2017.

\section{SERUM COLLECTION AND BIOCHEMICAL ANALYSIS}

The blood was collected in sterile plastic test tubes without anticoagulant (EDTA). The tubes were kept in a slanting plastic rack at room temperature to allow the blood to clot. The clotted blood was centrifuged for $10 \mathrm{~min}$ at 12000 rotations per min (rpm). A clear fluid which is the serum was pipetted out into a clean and sterilized 1.5 $\mathrm{mL}$ sterile Eppendorf tube for further analysis (Wright 1972). For each sample, $800 \mu \mathrm{L}$ of serum was applied to numbered sample wells. Total protein (TP), albumin (ALB), globulin (GLB), alkaline/globulin ratio (A/G ratio), alkaline phosphatase (AP), aspartate aminotransferase (AST) and alanine transaminase (ALT) were determined using assay kits (Biosino Bio-technology and Science Inc, Beijin, China) (Ye et al. 2006).

\section{STATISTICAL ANALYSIS}

No significant differences were found among any of the replicate means $(p>0.05)$, and the data for the different replicates were therefore averaged (Dean \& Voss 1999). Prior to statistical analysis, all data were tested for normality of distribution using the Kolmogornov-Smirnov test (Zar 1984) and homogeneity of variances was tested using Bartlett's test (Sokal \& Rohlf 1995). Two-way analysis of variance (ANOVA) was performed by a Student-NewmanKeuls multiple comparison test where the temperature and diet regimes as independent variable was applied to identify differences among treatments. In cases where the ANOVAreported significant differences, a pairwise post-hoc Tukey test was used to determine specifically which groups were different (Zar 1984). A significance level $(\alpha)$ of 0.05 was used if not stated otherwise. All data are presented as mean values \pm SE. All statistical analyses were carried out using the Minitab ${ }^{\mathrm{TM}}$ software version 14 , Origin ${ }^{\mathrm{TM}}$ software version 9 and SPSS ${ }^{\mathrm{TM}}$ software, version 20.

\section{RESULTS}

\section{WATER QUALITY PARAMETERS}

Mean values \pm SE of physico-chemical parameters recorded in experimental tanks during this study are presented in Table 1 . They were stable at the nominal treatment levels of $22,26,30$, and $34^{\circ} \mathrm{C}$ (both in pellet and shrimp diet) and no significant difference $(p>0.05)$ was observed in all the parameters. These values are within suitable ranges for culture of this species (Marković et al. 2009).

\section{EFFECT OF TEMPERATURE AND DIET ON HAEMATOLOGICAL PARAMETERS}

The experimental temperatures and offering diets had significant effect on several measured and calculated blood 
TABLE 1. Physico-chemical parameters (values are presented in mean $\pm \mathrm{SE}$ ) measured during the experiment

\begin{tabular}{lcccccccc}
\hline \multirow{2}{*}{ Parameters } & \multicolumn{2}{c}{$22^{\circ} \mathrm{C}$} & \multicolumn{2}{c}{$26^{\circ} \mathrm{C}$} & \multicolumn{2}{c}{$30^{\circ} \mathrm{C}$} & \multicolumn{2}{c}{$34^{\circ} \mathrm{C}$} \\
\cline { 2 - 10 } & Pellet & Shrimp & Pellet & Shrimp & Pellet & Shrimp & Pellet & Shrimp \\
\hline $\mathrm{T}\left({ }^{\circ} \mathrm{C}\right)$ & $22 \pm 0.56$ & $22 \pm 0.28$ & $26 \pm 0.14$ & $26 \pm 0.12$ & $30 \pm 0.29$ & $30 \pm 0.29$ & $34 \pm 0.29$ & $34 \pm 0.17$ \\
Salinity (psu) & $30 \pm 0.45$ & $30 \pm 0.26$ & $30 \pm 0.34$ & $30 \pm 0.22$ & $30 \pm 0.36$ & $30 \pm 0.24$ & $30 \pm 0.12$ & $30 \pm 0.28$ \\
$\mathrm{TH}\left(\mathrm{mg} \mathrm{L}^{-1}\right)$ & $119.33 \pm 22.33$ & $111.64 \pm 17.06$ & $108.07 \pm 18.41$ & $101.1 \pm 9.25$ & $125.4 \pm 16.49$ & $111.33 \pm 3.12$ & $97 \pm 3.89$ & $103.8 \pm 13.23$ \\
$\mathrm{NH}_{3}-\mathrm{N}\left(\mathrm{mg} \mathrm{L}^{-1}\right)$ & $0.25 \pm 0.20$ & $0.08 \pm 0.12$ & $0.25 \pm 0.20$ & $0.17 \pm 0.24$ & $0.33 \pm .24$ & $0.08 \pm 0.12$ & $0.42 \pm 0.24$ & $0.33 \pm 0.24$ \\
$\mathrm{pH}$ & $7.47 \pm 0.09$ & $7.42 \pm 0.17$ & $7.07 \pm 0.31$ & $7.53 \pm 0.21$ & $7.27 \pm 0.17$ & $7.37 \pm 0.29$ & $6.87 \pm 0.17$ & $7.17 \pm 0.25$ \\
\hline
\end{tabular}

*TH: total hardness and $\mathrm{NH}_{3}-\mathrm{N}$ : total ammonia nitrogen, ${ }^{\circ} \mathrm{C}=$ degree celcius, SE: Standard Error

variables (Table 2, Figure 2, $P<0.05$ ). The two-way ANOVA analysis showed temperature had significant effects $(P<$ $0.05)$ in all parameters except BW, MCV, MCHC and WBC. Diet variations also impact significantly $(P<0.05)$ on TL, BW, RBC, HB, and HCT. Conversely, no significant $(P>$ $0.05)$ effect was found in any of the measured parameter.
In particular, $\mathrm{RBC}, \mathrm{HB}, \mathrm{HCT}$ and TC levels were significantly lower $(P<0.05)$ in groups $22^{\circ} \mathrm{C}$ and $34^{\circ} \mathrm{C}$ with respect to group $26^{\circ} \mathrm{C}$ and $30^{\circ} \mathrm{C}$. High level of haematological parameters were recorded in $30^{\circ} \mathrm{C}$, followed by $26^{\circ} \mathrm{C}, 34^{\circ} \mathrm{C}$ and $22^{\circ} \mathrm{C}$. In all the parameters the values are higher in shrimp diet compared to that of pellet diet. But, in all the

TABLE 2. Results of the 2-way ANOVA analyses that were used to examine the effects of temperature and diet on haematological parameters of L. malabaricus juveniles

\begin{tabular}{|c|c|c|c|c|c|c|}
\hline Parameter & Source & $d f$ & $S S$ & $M S$ & $F$ & $P$ \\
\hline TL & $\begin{array}{c}\text { Temperature } \\
\text { Diet } \\
\text { Temp * Diet }\end{array}$ & $\begin{array}{l}3 \\
1 \\
3\end{array}$ & $\begin{array}{c}123.746 \\
12.100 \\
3.230\end{array}$ & $\begin{array}{c}41.2487 \\
12.1000 \\
1.0767\end{array}$ & $\begin{array}{c}57.44 \\
16.85 \\
1.50\end{array}$ & $\begin{array}{c}<0.001 * * \\
<0.001 * * \\
0.233\end{array}$ \\
\hline BW & $\begin{array}{l}\text { Temperature } \\
\text { Diet } \\
\text { Temp * Diet }\end{array}$ & $\begin{array}{l}3 \\
1 \\
3\end{array}$ & $\begin{array}{c}16575.5 \\
1024.1 \\
223.8\end{array}$ & $\begin{array}{c}5525.16 \\
1024.14 \\
74.60\end{array}$ & $\begin{array}{c}34.13 \\
6.33 \\
0.46\end{array}$ & $\begin{array}{c}<0.001 * * \\
0.017 * \\
0.712\end{array}$ \\
\hline $\mathrm{RBC}$ & $\begin{array}{c}\text { Temperature } \\
\text { Diet } \\
\text { Temp * Diet }\end{array}$ & $\begin{array}{l}3 \\
1 \\
3\end{array}$ & $\begin{array}{l}2.931 \\
0.841 \\
0.059\end{array}$ & $\begin{array}{c}0.977 \\
0.841 \\
0.019667\end{array}$ & $\begin{array}{c}15.00 \\
12.91 \\
0.30\end{array}$ & $\begin{array}{c}<0.001 * * \\
0.001 * * \\
0.824\end{array}$ \\
\hline HG & $\begin{array}{c}\text { Temperature } \\
\text { Diet } \\
\text { Temp * Diet }\end{array}$ & $\begin{array}{l}3 \\
1 \\
3\end{array}$ & $\begin{array}{c}173.221 \\
41.616 \\
1.918\end{array}$ & $\begin{array}{c}57.7403 \\
41.6160 \\
0.6393\end{array}$ & $\begin{array}{c}38.27 \\
27.59 \\
0.42\end{array}$ & $\begin{array}{c}<0.001 * * \\
<0.001 * * \\
0.737\end{array}$ \\
\hline HCT & $\begin{array}{c}\text { Temperature } \\
\text { Diet } \\
\text { Temp * Diet }\end{array}$ & $\begin{array}{l}3 \\
1 \\
3\end{array}$ & $\begin{array}{c}2042.0 \\
490.0 \\
42.4\end{array}$ & $\begin{array}{c}680.667 \\
490.000 \\
14.133\end{array}$ & $\begin{array}{c}21.25 \\
15.29 \\
0.44\end{array}$ & $\begin{array}{c}<0.001 * * \\
<0.001 * * \\
0.725\end{array}$ \\
\hline $\mathrm{MCV}$ & $\begin{array}{c}\text { Temperature } \\
\text { Diet } \\
\text { Temp * Diet }\end{array}$ & $\begin{array}{l}3 \\
1 \\
3\end{array}$ & $\begin{array}{c}1923.2 \\
383.3 \\
242.0\end{array}$ & $\begin{array}{c}641.07 \\
383.33 \\
80.67\end{array}$ & $\begin{array}{l}0.48 \\
0.28 \\
0.06\end{array}$ & $\begin{array}{c}0.701 \\
0.597 \\
0.98\end{array}$ \\
\hline $\mathrm{MCH}$ & $\begin{array}{c}\text { Temperature } \\
\text { Diet } \\
\text { Temp * Diet }\end{array}$ & $\begin{array}{l}3 \\
1 \\
3\end{array}$ & $\begin{array}{c}401.37 \\
66.51 \\
3.58\end{array}$ & $\begin{array}{c}133.789 \\
66.513 \\
1.195\end{array}$ & $\begin{array}{l}3.38 \\
1.68 \\
0.03\end{array}$ & $\begin{array}{l}0.030^{*} \\
0.204 \\
0.993\end{array}$ \\
\hline $\mathrm{MCHC}$ & $\begin{array}{c}\text { Temperature } \\
\text { Diet } \\
\text { Temp * Diet }\end{array}$ & $\begin{array}{l}3 \\
1 \\
3\end{array}$ & $\begin{array}{c}22.522 \\
4.586 \\
1.474\end{array}$ & $\begin{array}{l}7.5074 \\
4.5861 \\
0.4912\end{array}$ & $\begin{array}{l}0.42 \\
0.25 \\
0.03\end{array}$ & $\begin{array}{l}0.742 \\
0.617 \\
0.994\end{array}$ \\
\hline $\mathrm{TC}$ & $\begin{array}{c}\text { Temperature } \\
\text { Diet } \\
\text { Temp * Diet }\end{array}$ & $\begin{array}{l}3 \\
1 \\
3\end{array}$ & $\begin{array}{c}1521.88 \\
65.02 \\
57.28\end{array}$ & $\begin{array}{c}507.292 \\
65.025 \\
19.092\end{array}$ & $\begin{array}{l}35.66 \\
4.57 \\
1.34\end{array}$ & $\begin{array}{c}<0.001 * * \\
0.04 * \\
0.278\end{array}$ \\
\hline WBC & $\begin{array}{c}\text { Temperature } \\
\text { Diet } \\
\text { Temp * Diet }\end{array}$ & $\begin{array}{l}3 \\
1 \\
3\end{array}$ & $\begin{array}{c}253.39 \\
1.52 \\
15.96\end{array}$ & $\begin{array}{c}84.4647 \\
1.5210 \\
5.3203\end{array}$ & $\begin{array}{l}3.27 \\
0.06 \\
0.21\end{array}$ & $\begin{array}{c}0.034^{*} \\
0.81 \\
0.892\end{array}$ \\
\hline
\end{tabular}

*temperature: $22,26,30,34^{\circ} \mathrm{C}$; diet: pellet, shrimp. T $\times$ D: Temperature $\left({ }^{\circ} \mathrm{C}\right) \times \mathrm{Die}$ 
(a)

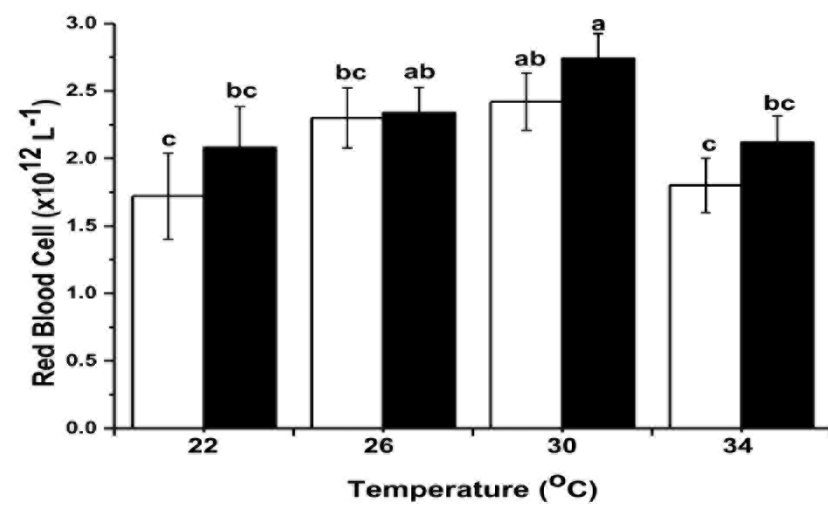

(c)

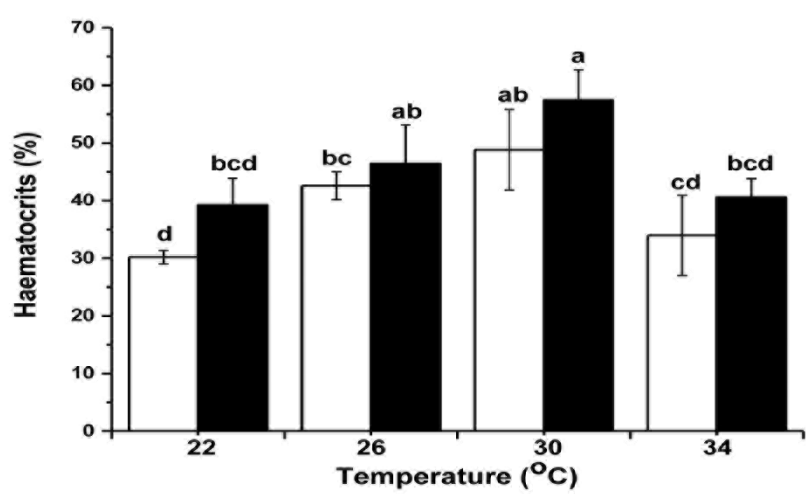

(e)

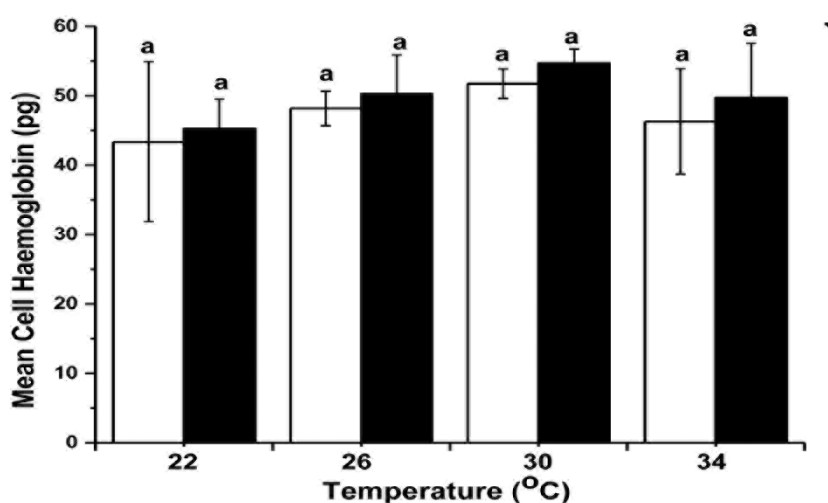

(g)

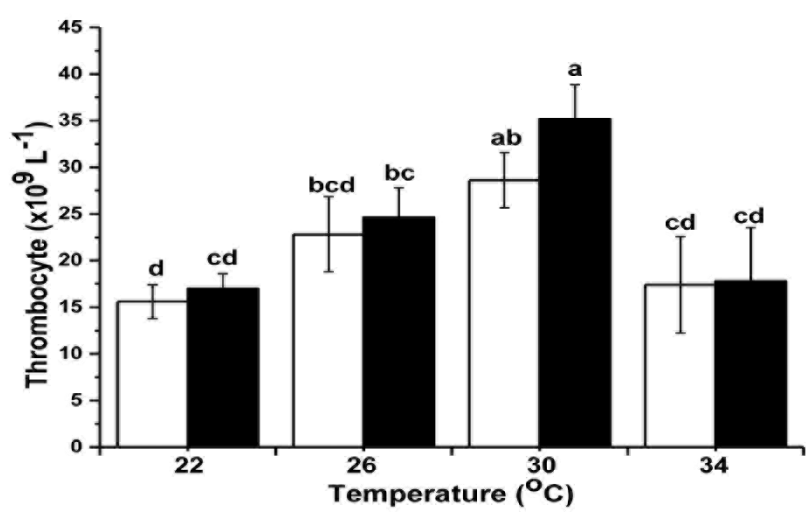

(b)

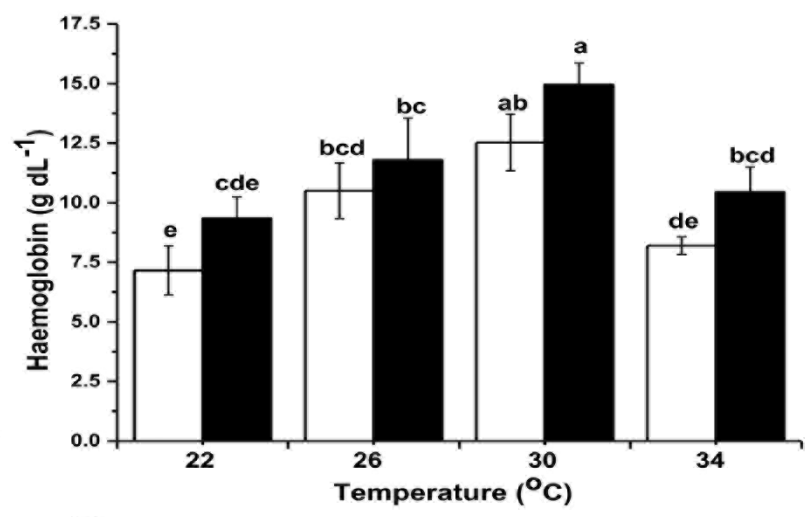

(d)

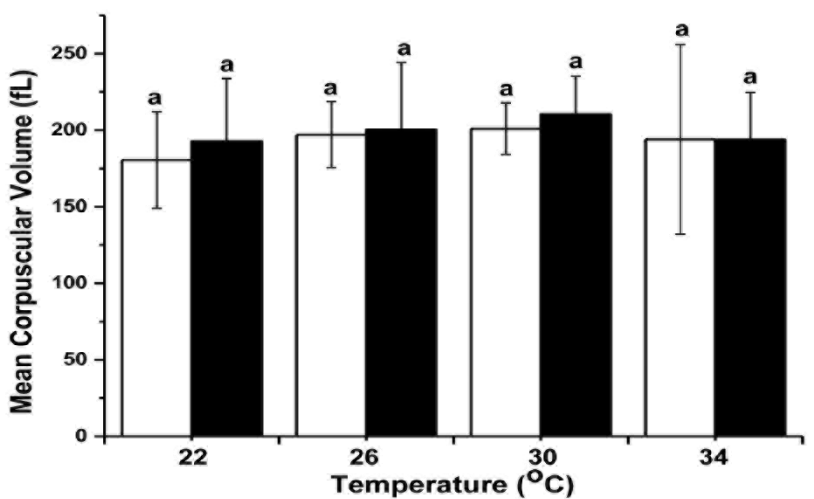

(f)

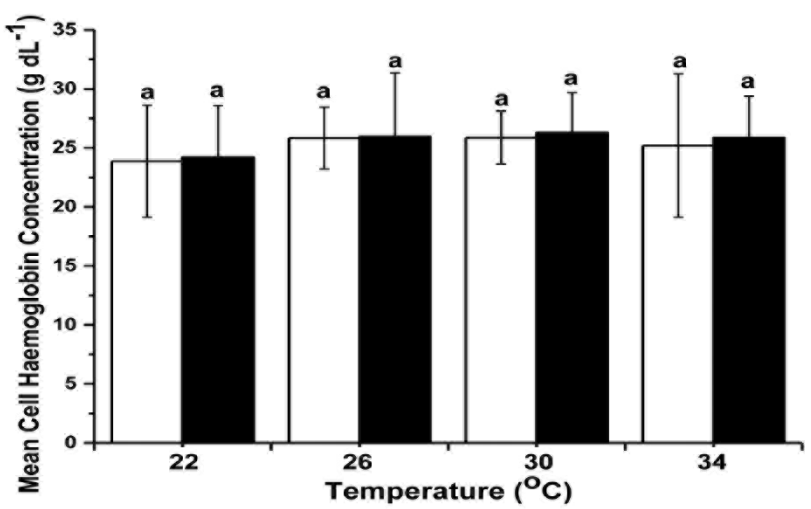

(h)

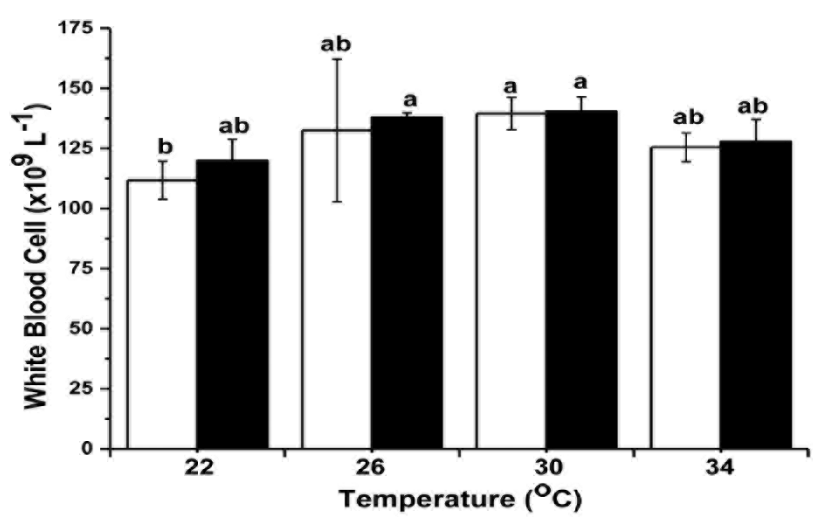

FIGURE 2. Effects of temperature and diet on haematological parameters of L. malabaricus evaluated with four different temperatures and two different diets $(n=120)$. Values are given 95\% CIs for mean based on pooled StDev. The white bar shows pellet and the dense bar shows Shrimp diet. Bars bearing different letters are significantly different from each other 
temperatures the values are not significantly different $(p>$ $0.05)$ between the two diets except TL $(p<0.05)$ at $26^{\circ} \mathrm{C}$.

The decrease in the haematocrit values and increased WBC values clearly indicated cold and heat shock stress. In hypochromic anaemia there is a decrease in cell haemoglobin and thus the $\mathrm{MCH}$ value will be decreased. However, in macrocytic condition the $\mathrm{MCH}$ will be increased.

\section{EFFECT OF TEMPERATURE AND DIET ON BIOCHEMICAL PARAMETERS}

The calculated biochemical parameters in respect of temperature and diet effects are shown in Table 3 and Figure 3 . Total serum proteins showed higher values in groups $30^{\circ} \mathrm{C} \& 26^{\circ} \mathrm{C}$ with respect to group $34^{\circ} \mathrm{C} \& 22^{\circ} \mathrm{C}$. These differences show changes in the relative protein fractions. Albumin showed similar trend, increasing by $26.1 \%$ from the lowest at $22^{\circ} \mathrm{C}$ with pellet diet to that of $30^{\circ} \mathrm{C}$ feeding with shrimp diet group and represents the main contributor in rising levels of total plasma proteins. However, globulin levels decreased by $15.7 \%$ from the value of $22^{\circ} \mathrm{C}$ in pellet feed group to $30^{\circ} \mathrm{C}$ (from 16.6 to $\left.14.0 \mathrm{~g} \mathrm{~L}^{-1}\right)$ in shrimp group. However, the variations in total serum proteins, albumin and globulin are not significant $(P>0.05)$. Ratio of A/G (Albumin/Globulin) increased significantly $(p<0.05)$ by $49.4 \%\left(1.66\right.$ in $22^{\circ} \mathrm{C}$ pellet group to 2.483 in $30^{\circ} \mathrm{C}$ shrimp group). Similarly, AST and ALT level showed the highest levels in $30^{\circ} \mathrm{C}$ group and follow the similar increasing trend from $22^{\circ} \mathrm{C}$ to $30^{\circ} \mathrm{C}$ and again decrease to further increasing the temperature to $34^{\circ} \mathrm{C}$ but the variations are not significant $(p>0.05)$. Conversely, significant interaction between temperature and diet was found for ALT $(p<0.05)$. Similar the haematological parameters, the values of all the biochemical parameters are higher in shrimp feeding group than that of pellet feeding group at all the temperatures except globulin. However, there was no significant difference $(p<0.05)$ observed in diet variations in any of the temperature except $\mathrm{A} / \mathrm{G}$ ratio and AP where the variations were significant at $26^{\circ} \mathrm{C}(p<$ $0.05)$. The two-way ANOVAanalysis showed that changing rearing temperature had significant effect $(p<0.05)$ on biochemical parameters except TP $(p<0.05)$, and diet variations had significant variations only on $\mathrm{A} / \mathrm{G}$ ratio and AP $(p<0.05)$. But there was no significant effect on temperature and diet interaction in any of the biochemical parameter (Table 3, $p>0.05$ ).

\section{DISCUSSION}

Fish are intimately associated with the aqueous environment; physical and chemical changes in the environment are rapid and reflected as measurable physiological changes in fish especially haematological and biochemical parameters (Atamanalp et al. 2002; Ferreira et al. 2011). Our results for L. malabaricus showed a significant influence in different levels of temperature and diet variations on most of the haematological and biochemical parameters studied. The result of the present investigation showed that the effect

TABLE 3. Results of the 2-way ANOVA analyses that were used to examine the effects of temperature and diet on biochemical parameters of L. malabaricus juveniles

\begin{tabular}{ccccccc}
\hline Parameter & Source & $d f$ & $S S$ & $M S$ & $F$ & $P$ \\
\hline \multirow{3}{*}{ TP } & Temperature & 3 & 97.275 & 32.4250 & 1.57 & 0.215 \\
& Diet & 1 & 9.025 & 9.0250 & 0.44 & 0.513 \\
& Temp * Diet & 3 & 1.875 & 0.6250 & 0.03 & 0.993 \\
Alb & Temperature & 3 & 194.075 & 64.6917 & 5.23 & $0.005^{*}$ \\
& Diet & 1 & 27.225 & 27.2250 & 2.20 & 0.148 \\
& Temp * Diet & 3 & 6.075 & 2.0250 & 0.16 & 0.92 \\
Glb & Temperature & 3 & 17.0 & 5.66667 & 3.11 & $0.04 *$ \\
& Diet & 1 & 4.9 & 4.90000 & 2.68 & 0.111 \\
& Temp * Diet & 3 & 3.3 & 1.10000 & 0.60 & 0.618 \\
A/G ratio & Temperature & 3 & 2.08040 & 0.693467 & 22.07 & $<0.001 * *$ \\
& Diet & 1 & 0.44721 & 0.447211 & 14.23 & $0.001 * *$ \\
& Temp * Diet & 3 & 0.19846 & 0.066155 & 2.11 & 0.119 \\
AP & Temperature & 3 & 10166.3 & 3388.76 & 59.83 & $<0.001 * *$ \\
& Diet & 1 & 1010.0 & 1010.02 & 17.83 & $<0.001 * *$ \\
& Temp*Diet & 3 & 179.3 & 59.76 & 1.06 & 0.382 \\
AST & Temperature & 3 & 393.8 & 131.267 & 2.36 & 0.09 \\
& Diet & 1 & 40.0 & 40.000 & 0.72 & 0.403 \\
& Temp*Diet & 3 & 1.0 & 0.333 & 0.01 & 0.999 \\
ALT & Temperature & 3 & 404.297 & 134.766 & 13.87 & $<0.001 * *$ \\
& Diet & 1 & 36.864 & 36.864 & 3.80 & 0.06 \\
& Temp*Diet & 3 & 4.722 & 1.574 & 0.16 & 0.921 \\
\hline
\end{tabular}

*temperature: $22,26,30,34{ }^{\circ} \mathrm{C}$; diet: pellet, shrimp. T $\times$ D: Temperature $\left({ }^{\circ} \mathrm{C}\right) \times$ Diet 
(a)

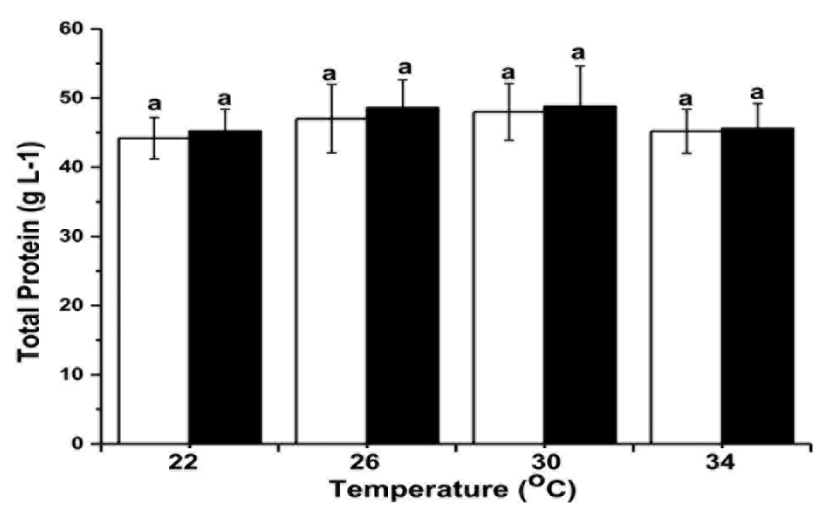

(c)

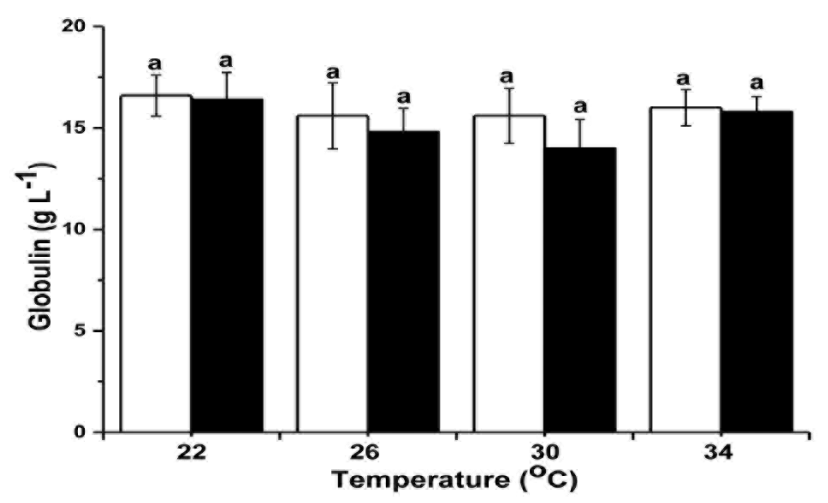

(e)

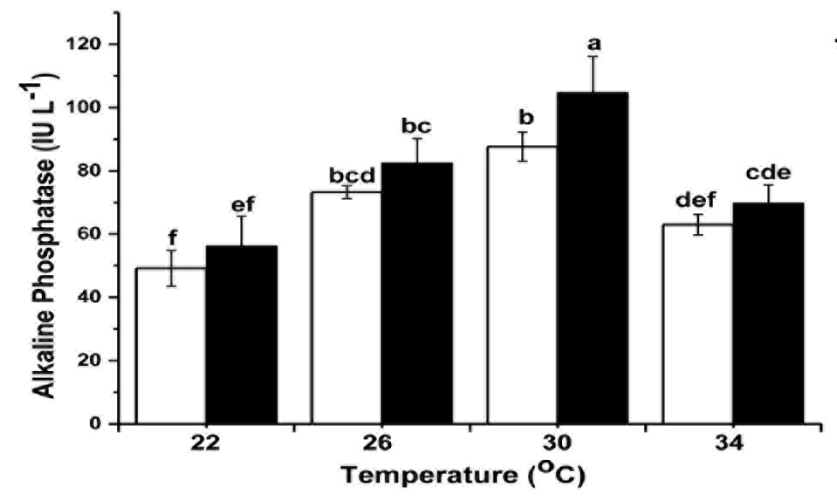

(g)

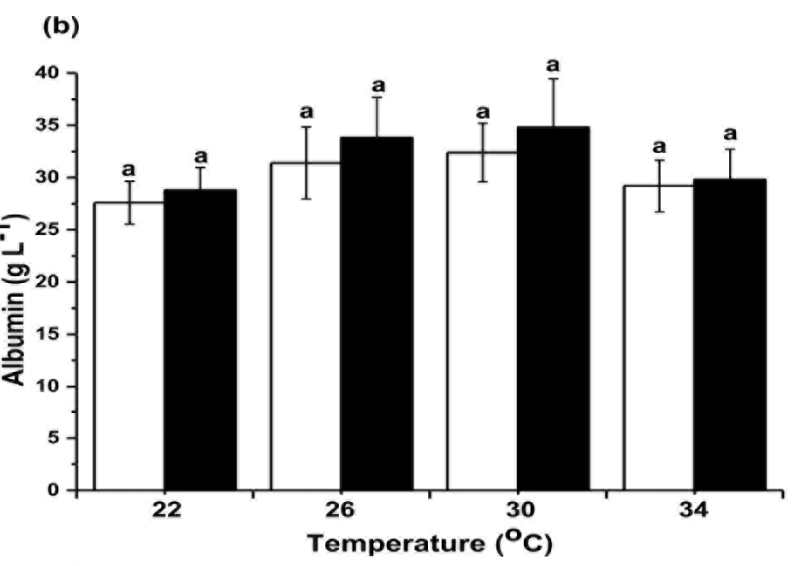

(d)

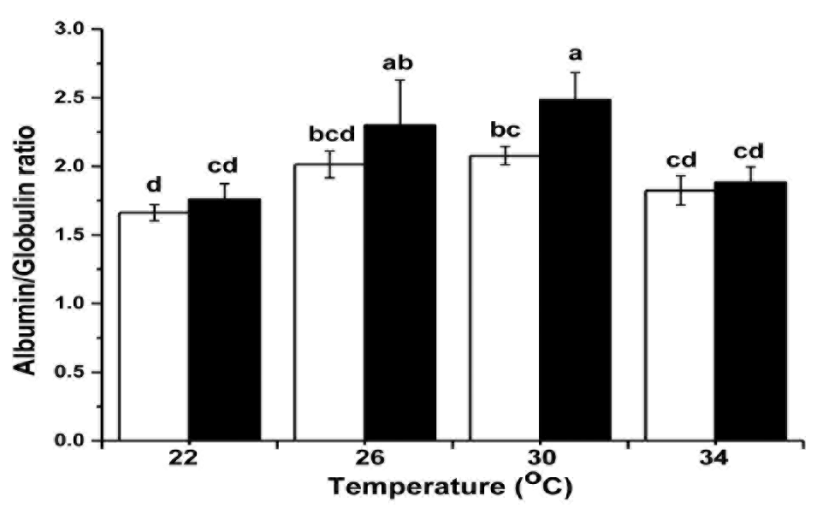

(f)

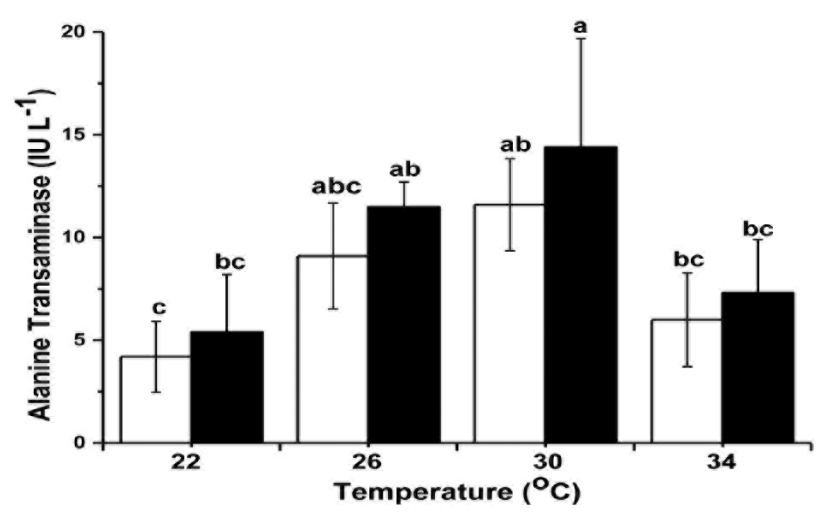

FIGURE 3. Effects of temperature and diet on biochemical parameters of L. malabaricus evaluated with four temperatures and two diets. Values are given 95\% CIs for mean based on pooled StDev. The white bar shows pellet and dense bar shows Shrimp diet.

Bars bearing different letters are significantly different from each other 
of low and high temperature on blood parameter of $L$. malabaricus decreased the RBC, $\mathrm{HB}, \mathrm{HCT}, \mathrm{MCV}, \mathrm{MCH}$, $\mathrm{TC}$ and $\mathrm{WBC}$ content but increased in MCHC (at low or high temperature). The values detected in our present experiment are in agreement with those found by Lermen et al. (2004) and Rhamdia and de Moraes (2002) who studied hematologic characteristics of Rhamdia quelen. Bhatt and Singh (1985) and Joshi et al. (1980) observed similar results when Clarias batrachus and Schizothorax plagiostomus were exposed to cold and heat stress. RBC count in the range $1.72-2.72 \times 10^{12} \mathrm{~L}^{-1}$ in L. malabaricus were within the range described by Adeymo et al. (2003) and a similar observation was noted in tilapia reported by Adam (2004) and Terry et al. (2000). At low temperatures, a decrease in RBC in Phreatichthys andruzzii is related to reduce erythropoiesis (Gabriel et al. 2005; Hofer et al. 2000). Increased RBC level with increasing temperature is probably related to a higher oxygen uptake. When the number of RBC decreased, HB level decreased. HB concentration (7.16-14.96 $\left.\mathrm{g} \mathrm{dL}^{-1}\right)$ in the present study was similar to those reported by Adeymo et al. (2003) and Gabriel et al. (2005) in Red Tilapia (7.3 $\left.\mathrm{g} \mathrm{dL}^{-1}\right)$, Nile Tilapia (10.4 $\left.\mathrm{g} \mathrm{dL}^{-1}\right)$, Curimbata $\left(9.7 \mathrm{~g} \mathrm{dL}^{-1}\right)$ and hybrid Tilapia (12.7 $\left.\mathrm{g} \mathrm{dL}^{-1}\right)$. Decreasing trend of HB during the cold temperature has been reported in many species (Chen et al. 2005; Staurnes et al. 1994). The mean values of HCT in L. malabaricus obtained from this study were within the range of the corresponding values (Gabriel et al.2005; Munkittrick \& Leatherland 1983). Several of these studies attempted to determine whether significant variations from normal values of these parameters do exist and could be attributable to some internal or external factors. Haematology studies in teleosts have indicated that HCT values might be useful as a general indicator of fish health, since fish given iron deficient diets, or those exhibiting anaemia, all possess reduced HCT values (Wilson \& Taylor 1993). In this study, the increase of HCT was found in thermally treated fish what is consistent with the research of Barton (Gubbins et al.2000) that HCT is a measure of the cellular fraction of blood and is a common stress indicator for fish. A significant increase of HCT was established in Carassius gibelio after it had been exposed to the ambient temperature elevation of $10^{\circ} \mathrm{C}$ (Dekić et al. 2014).

In the present study the range of MCV (180-210.3 fL), MCH (43.38-54.65 pg) and MCHC (23.87-26.29) obtained from this study were similar to findings of Gabriel et al. (2005) and Terry et al. (2000). According to these authors, these variations might be influenced by different conditions like temperature, feeding, gender, age, origin, and breeding system. In fish blood WBC are the major cell components involved in immune responses although some authors suggest that fish TC also participate in defence mechanisms by means of their phagocytic ability (Stosik et al. 2001). WBC levels in blood vary according to environmental temperature and nutritional state (Barros et al. 2002). The WBC and TC decrease indicates a weakened defence (immunosuppression) and delay clotting in the event of an injury to the fish in the new environment. When temperature changed from the optimum, the number of $\mathrm{TC}$ and WBC also changed, with increasing temperature, the number of TC and WBC also increased in blood. The present results demonstrate that L. malabaricus showed the classical stress response either to cold or heat shock. Cold shock was more stressful to L. malabaricus than heat shock.

In the present study, TL, BW, RBC, Hb, Hct, PC and WBC were also significantly changed with changing diet. The previous studies suggest that incorporation of appropriate levels of dietary feed can improve their growth performance, physical quality and to provide an inexpensive non-nitrogenous energy source (Vielma et al. 2003). However, excess or inappropriate levels of fish feed often accompanied by poor feed utilization (Enes et al. 2006). Temperature influences the physiological characteristics of ectotherms, and it also modulates utilization of nutrients by fish (Enes et al. 2006). Abdelghany (2002) showed that replacement of fish meal partially or totally by Gambusia meal in diets for common carp (Cyprinus carpio) fingerlings did not affect significantly RBC counts $\left(3.08-3.17 \times 10^{6} \mathrm{~mm}^{-3}\right)$ but it improved significantly Hct (27.53-35.07\%). His figures are very close to the findings of the current study. Moradi et al. (2013) evaluated the hematological and biochemical changes induced by replacing fish meal with plant protein in the $C$. carpio fed and indicated significant differences in HB and HCT while no significant differences were found in RBC and WBC. Yue and Zhou (2008) showed replacing soybean meal with cottonseed meal decreases WBC, RBC, $\mathrm{Hct}$ and $\mathrm{Hb}$ at juvenile hybrid tilapia. Indeed, animals fed protein calorie malnourish diets have been reported to have significant reduction in haematocrit and hemoglobin concentration (Bolarinwa et al. 1991). WBC results recorded in this study showed an increase in the shrimp diet. The highest value of $140.4 \times 10^{9} \mathrm{~L}^{-1}$ for $\mathrm{WBC}$ was recorded in fish at $30^{\circ} \mathrm{C}$ fed shrimp diet. Weiss and Wardrop (2011) demonstrated that the amount has implication in immune responses and the ability of the animal to fight infection.

The ranges of serum biochemistry vary from species to species and can be influenced by many biotic and abiotic factors such as water temperature, food, age and sex of the fish (Jawad et al. 2004). Increased protein levels seen in temperature $26^{\circ} \mathrm{C}$ to $30^{\circ} \mathrm{C}$ groups with respect to that of cold $\left(22^{\circ} \mathrm{C}\right)$ and hot temperature $\left(34^{\circ} \mathrm{C}\right)$. And at each temperature the value was higher in shrimp diet than in pellet diet. The total plasma protein, albumin, globulin, $\mathrm{A} / \mathrm{G}$ ratio and alkaline phosphatase levels (19.2-48.8 $\mathrm{g} \mathrm{L}^{-1}$, 5.8-15.6 $\mathrm{g} \mathrm{L}^{-1}, 13.4-33.2 \mathrm{~g} \mathrm{~L}^{-1}, 1.66-2.48$ and 49.2-104.8 IU $\mathrm{L}^{-1}$, respectively) of studied L. malabaricus were similar to those reported by Tavares-Dias et al. (2000). These variations might be attributed to temperature changes which may affect the biochemical blood levels, although the data refer to fishes from tropical regions where temperature was more or less stable throughout the year (Adeyemo et al. 2003). The variations in the biochemical blood parameters might be due to the different biochemical metabolism in various seasons (Adeyemo et al. 2003; Chavin \& Young 
1970). The possible importance of increased serum protein as a fuel for tissues during osmotic acclimation has not been addressed yet, but may be related to a metabolic reallocation of energy resources once carbohydrate stores have been mobilized. Total proteins can be useful as biomarkers of different aquatic habitats of fish (MacedaVeiga et al. 2010). Abdelghany (2002) reported values of total protein between 27.1 and $43.7 \mathrm{gm} \mathrm{L}^{-1}$ in C. carpio fingerlings fed diets with different levels of Gambusia meal as partial or total replacements of fish meal. These values resemble well those reported in the current study. The study of Moradi et al. (2013) on the haematological and biochemical changes induced by replacing fish meal with plant protein in the common carp C.carpio, indicated that experimental diets showed significant differences in total protein levels. AST and ALT, found mainly in hepatocytes and cardiomyocytes of fish, respectively, play important roles in protein metabolism. When liver and myocardial cells are damaged or their permeability increases, AST and ALT will be released into the blood, resulting in elevated blood transaminase activity. The activities of serum AST and ALT can, therefore, be used to monitor the health status of fish (Yuan et al. 2005). In the present study, values of AST and ALT at different level of temperature and diet did change but the values are still in normal range indicating that fish were in good condition. However, the variation in haematological and biochemical parameters obtained in this study emphasizes the need of more study on large number of fish population at different seasons and different age, sex and environmental conditions to fill the lack of knowledge about L. malabaricus.

\section{CONCLUSION}

In conclusion, this study has provided valuable information for fish biologist in the assessment of fish health and in monitoring stress response, and we assume that variation in values of blood indices may be a defensive mechanism against stress induced by acclimation. This is the first study on L. malabaricus to monitor the impact of temperature and diet in haematological and biochemical parameters. The variations in haematological and biochemical parameters due to different temperature and different feeding management emphasize the fact that changes in blood characteristics are important indices in monitoring the management on the fish physiology. Therefore, establishing a baseline of information, as this work contributes to, on fish blood profile as a monitoring tool for aquaculture systems may improve the welfare and production of farmed fish.

\section{ACKNOWLEDGEMENTS}

We would like to thank anonymous reviewers for their comments. This study was financially supported by the Ministry of Science Technology and Innovation, Malaysia through the research grant \# 04-01-02-SF1208, and Institute of Climate change, Universiti Kebangsaan Malaysia through the research grant 'GUP-2017-023' and UKM-Sime Darby Foundation Chair in Climate Change grant: 'ZF2019-003' to the corresponding author.

\section{REFERENCES}

Abdelghany, A.E. 2002. Studies on partial and complete replacements of fish meal with Gambusia meal in diets for the common carp, Cyprinus carpio. Egyptian Journal of Aquatic Biology and Fisheries 6: 141-765.

Adam, H. 2004. Comparative studies on the effect of water quality on haematological of Orechromis niloticus under culture condition. Ph.D. Thesis of Sudan University of Science and Technology (Unpublished).

Adeyemo, O., Agbede, S., Olaniyan, A. \& Shoaga, O. 2003. The haematological response of Clarias gariepinus to changes in acclimation temperature. African Journal of Biotechnology 6: 105-108.

Akinrotimi, A., Gabriel, U., Anyanwu, P. \& Anyanwu, A. 2007. Influence of sex, acclimation methods and period on haematology of Sarotherodon melanotheron (Cichilidae). Research Journal of Biological Sciences 2(3): 348-352.

Atamanalp, M., Yanik, T., Haliloglu, H.Ï. \& Aras, M.S. 2002. Alterations in the hematological parameters of rainbow trout, Oncorhynchus mykiss, exposed to cypermethrin. Israeli Journal of Aquaculture-Bamidgeh 54(3): 99-103.

Barros, M.M., Pezzato, L.E., Kleemann, G.K., Hisano, H. \& Rosa, G.D.M. 2002. Níveis de vitamina C e ferro para tilápia do Nilo (Oreochromis niloticus). Revista Brasileira de Zootecnia 31: 2149-2156.

Barton, B.A. 2002. Stress in fishes: A diversity of responses with particular reference to changes in circulating corticosteroids. Integrative and Comparative Biology 42: 517-525.

Bhatt, S. \& Singh, H. 1985. Effect of thermal variation on some haematological values of Schizothorax plagiostomus (Heckel). Uttar Pradesh Journal of Zoology 5: 204-209.

Bolarinwa, A., Oyebola, D. \& Akindeinde, G. 1991. Effect of malnutrition on basal and induced gastric acid secretion. Nigerian Journal of Physiological Sciences 5: 144-148.

Chavin, W. \& Young, J.E. 1970. Factors in the determination of normal serum glucose levels of goldfish, Carassius auratus L. Comparative Biochemistry and Physiology 33: 629-653.

Chen, Y., Jin, S. \& Wang, G. 2005. Study on blood physiological and biochemical indices of Vibrio alginilyticus disease of Lateolabrax japonicas. Journal of Oceanography in Taiwan Strait 24: 104-108.

Das, S.K., Ghaffar, M.A., Bakar, Y., Brito, M.F.G., Sharifah, M.S.A. \& Temple, S.E. 2014. X-radiographic observations of food passage and nutrient absorption along the alimentary tract of archerfish, Toxotes jaculatrix. Bulletin of Marine Science 90(4): 903-919.

Das, S.K., Noor, N.M., Kai, K.S., Juan, Q.Z., Iskandar, N.S.M. $\&$ De, M. 2018. Effects of temperature on the growth, gastric emptying time, and oxygen consumption rate of masheer (Tor tambroides) under laboratory conditions. Aquaculture Reports 12: 20-24.

De, M., Ghaffar, M.A., Bakar, Y. \& Das, S.K. 2016. Effect of temperature and diet on growth and gastric emptying time of

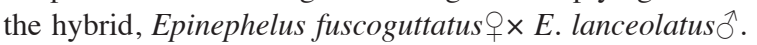
Aquaculture Reports 4: 118-124.

Dean,A. \& Voss, D. 1999. Response surface methodology. Design and Analysis of Experiments 1: 483-529. 
Dekić, R., Ivanc, A., Erić, Ž., Gnjato, R., Trbić, G., Lolić, S., Manojlović, M. \& Janjić, N. 2014. Hematological characteristics of Delminichthys ghetaldii (Steindachner 1882) inhabiting the karst region of eastern Herzegovina. Archives of Biological Sciences 66: 1423-1430.

Duncan, P.L., Lovell, R.T., Butterworth Jr., C., Freeberg, L.E. \& Tamura, T. 1993. Dietary folate requirement determined for channel catfish, Ictalurus punctatus. The Journal of Nutrition 123(11): 1888-1897.

Elahee, K. \& Bhagwant, S. 2007. Hematological and gill histopathological parameters of three tropical fish species from a polluted lagoon on the West Coast of Mauritius. Ecotoxicology and Environmental Safety 68: 361-371.

Enes, P., Panserat, S., Kaushik, S. \& Oliva-Teles, A. 2006. Rapid metabolic adaptation in European sea bass (Dicentrarchus labrax) juveniles fed different carbohydrate sources after heat shock stress. Comparative Biochemistry and Physiology - Part A: Molecular \& Integrative Physiology 145: 73-81.

Fazio, F., Marafioti, S., Arfuso, F., Piccione, G. \& Faggio, C. 2013. Influence of different salinity on haematological and biochemical parameters of the widely cultured mullet, Mugil cephalus. Marine and Freshwater Behaviour and Physiology 46: 211-218

Fazio, F., Faggio, C., Marafioti, S., Torre, A., Sanfilippo, M. \& Piccione, G. 2012. Comparative study of haematological profile on Gobius niger in two different habitat sites: Faro Lake and Tyrrhenian Sea. Cahiers de Biologie Marine 53: 213-219.

Ferguson, R., Merrifield, D.L., Harper, G.M., Rawling, M.D., Mustafa, S., Picchietti, S., Balcàzar, J.L. \& Davies, S.J. 2010. The effect of Pediococcus acidilactici on the gut microbiota and immune status of on-growing red tilapia (Oreochromis niloticus). Journal of Applied Microbiology 109: 851-862.

Fernandes, M.N. \& Mazon,A.D.F. 2003. Environmental pollution and fish gill morphology. In Fish Adaptation, edited by Val, A.L. \& Kapoor, B.G. Enfield: Science Publishers. pp. 203-231.

Ferreira, F., Santos, M.M., Reis-Henriques, M.A., Vieira, M.N. \& Monteiro, N.M. 2011. The annual cycle of spermatogenesis in Lipophrys pholis (Blenniidae), a recently proposed sentinel species for pollution monitoring. Ichthyological Research 58: 360-365.

Forghally,A., Ezzat, A. \& Shabana, M. 1973.Effect of temperature and salinity changes on the blood characteristics of Tilapia zilli in Egyptian littoral lakes. Comparative Biochemistry and Physiology Part A: Physiology 46: 183-193.

Gabriel, U., Ezeri, G. \& Opabunmi, O. 2005. Influence of sex, source, health status and acclimation on the haematology of Clarias gariepinus (Burch, 1822). African Journal of Biotechnology 3(9): 463-467.

Gollock, M., Currie, S., Petersen, L. \& Gamperl, A. 2006. Cardiovascular and haematological responses of Atlantic cod (Gadus morhua) to acute temperature increase. Journal of Experimental Biology 209: 2961-2970.

Gubbins, M., Eddy, F., Gallacher, S. \& Stagg, R. 2000. Paralytic shellfish poisoning toxins induce xenobiotic metabolising enzymes in Atlantic salmon (Salmo salar). Marine Environmental Research 50: 479-483.

Gunben, E.M., Senoo, S., Yong, A. \& Shapawi, R. 2014. High potential of poultry by-product meal as a main protein source in the formulated feeds for a commonly cultured grouper in Malaysia (Epinephelus fuscoguttatus). Sains Malaysiana 43(3): 399-405.
Hofer, R., Stoll, M., Romani, N., Koch, F. \& Sordyl, H. 2000. Seasonal changes in blood cells of Arctic char (Salvelinus alpinus L.) from a high mountain lake. Aquatic Sciences 62: 308-319.

Jawad, L., Al-Mukhtar, M. \& Ahmed, H. 2004. The relationship between haematocrit and some biological parameters of the Indian shad, Tenualosa ilisha (Family Clupeidae). Animal Biodiversity and Conservation 27: 47-52.

Joshi, B., Chaturvedi, L. \& Dabral, R. 1980. Some haematologic values of Clarias batrachus L. following its sudden transfer to varying temperature. Indian Journal of Experimental Biology 18: 76-77.

Lermen, C.L., Lappe, R., Crestani, M., Vieira, V.P., Gioda, C.R., Schetinger, M.R.C., Baldisserotto, B., Moraes, G. \& Morsch, V.M. 2004. Effect of different temperature regimes on metabolic and blood parameters of silver catfish Rhamdia quelen. Aquaculture 239(1-4): 497-507.

Maceda-Veiga, A., Monroy, M., Viscor, G. \& De Sostoa, A. 2010. Changes in non-specific biomarkers in the Mediterranean barbel (Barbus meridionalis) exposed to sewage effluents in a Mediterranean stream (Catalonia, NE Spain). Aquatic Toxicology 100: 229-237.

Maricondi-Massari, M., Kalinin,A., Glass, M. \& Rantin, F. 1998. The effects of temperature on oxygen uptake, gill ventilation and ECG waveforms in the Nile tilapia, Oreochromis niloticus. Journal of Thermal Biology 23: 283-290.

Marković, Z., Dulić, Z., Živić, I. \& Mitrović-Tutundžić, V. 2009. Influence of abiotic and biotic environmental factors on weight gain of cultured carp on a carp farm. Archives of Biological Sciences 61: 113-121.

Mazumder, S.K., Das, S.K., Rahim, S.M. \& Ghaffar, M.A. 2018a. Temperature and diet effect on the pepsin enzyme activities, digestive somatic index and relative gut length of Malabar blood snapper (Lutjanus malabaricus Bloch \& Schneider, 1801). Aquaculture Reports 9: 1-9.

Mazumder, S.K., Ghaffar, M.A. \& Das, S.K. 2018b. Exploring the suitable temperature and diet for growth and gastric emptying time of juvenile malabar blood snapper (Lutjanus malabaricus Bloch \& Schneider, 1801). Thalassas: An International Journal of Marine Sciences 35(1): 29-41.

Mazumder, S.K., Das, S.K., Bakar, Y. \& Ghaffar, M.A. 2016. Effects of temperature and diet on length-weight relationship and condition factor of the juvenile Malabar blood snapper (Lutjanus malabaricus Bloch \& Schneider, 1801). Journal of Zhejiang University SCIENCE B 17(8): 580-590.

Mazumder, S.K., Mazlan, A., De, M., Zaidi, C., Rahim, S. \& Simon, K.D. 2014. Impact of global climate change on fish growth, digestion and physiological status: Developing a hypothesis for cause and effect relationships. Water and Environment Journal 6(2): 200-226.

Moradi, N., Imanpoor, M. \& Taghizadeh, V. 2013. Hematological and biochemical changes induced by replacing fish meal with plant protein in the Cyprinus carpio Linnaeus (1785). Global Veterinaria 11: 233-237.

Munkittrick, K. \& Leatherland, J. 1983. Haematocrit values in feral goldfish, Camssius auratus L., as indicators of the health of the population. Journal of Fish Biology 23: 153-161.

Noor, N.M., Das, S.K. \& Ghaffar, Z. 2018. Effect of salinities on gastric emptying and nutrient absorption of tiger grouper $\times$ giant grouper (Epinephelus fuscoguttatus $\times$ E. lanceolatus) hybrid. Sains Malaysiana 47(6): 1077-1084.

Pauly, D. 1995. Simulation of the effects of oxygen on food consumption and growth of Nile tilapia, Oreochromis niloticus (L.). Aquaculture Research 26: 427-440. 
Rahman, M.L., Salam, M.A. \& Ahsan, M.E. 2017. Proteinsparing ability of carbohydrates from different sources in diets for fry of stinging catfish Heteropneustes fossilis. Sains Malaysiana 46(2): 239-244.

Rhamdia, P.O.J. \& de Moraes, G.M.F.R. 2002. Características hematológicas de teleósteos brasileiros. IV. Variáveis do jundiá Rhamdia quelen (Pimelodidae). Ciência Rural 1: 693-698.

Rosenlund, G. \& Skretting, M. 2006. Worldwide status and perspective on gadoid culture. ICES Journal of Marine Science 63: 194-197.

Sharaf-El-Deen, K. \& Abdel-Hamid, N.A. 2002. Sublethal effects of copper sulfate malathion and paraquat on protein pattern of Oreochromis niloticus. Egyptian Journal of Aquatic Biology and Fisheries 6: 167-182.

Sokal, R.R. \& Rohlf, F.J. 1995. Biometry: The Principles and Practice of Statistics in Biological Research. San Francisco: WH. Freeman \& Co.

Staurnes, M., Rainuzzo, J.R., Sigholt, T. \& Jøgensen, L. 1994. Acclimation of Atlantic cod (Gadus morhua) to cold water: Sxtress response, osmoregulation, gill lipid composition and gill Na-K-ATPase activity. Comparative Biochemistry and Physiology - Part A: Molecular \& Integrative Physiology 109: 413-421.

Stosik, M., Deptula, W. \& Travnicek, M. 2001. Studies on the number and ingesting ability of thrombocytes in sick carps (Cyprinus carpio L.). Veterinární Medicína 46: 12-16.

Tavares-Dias, M., Frascá-Scorvo, C., Novato, P. \& Moraes, F. 2000. Hematological characteristics of hybrid Florida red tilapia, Oreochromis urolepis hornorun $\times O$. mossambicus under intensive rearing. Proceedings International Simposium on Tilapia Aquaculture. pp. 533-541.

Terry, C., Hrubee, T. \& Stephen, A. 2000. Haematology of fish. Eterinary Clinical Pathology 174: 1120-1125.

Treasurer, J.W., Hastie, L.C., Hunter, D., Duncan, F. \& Treasurer, C.M. 2006. Effects of (Margaritifera margaritifera) glochidial infection on performance of tank-reared Atlantic salmon (Salmo salar). Aquaculture 256: 74-79.

Vázquez, G.R. \& Guerrero, G. 2007. Characterization of blood cells and hematological parameters in Cichlasoma dimerus (Teleostei, Perciformes). Tissue and Cell 39: 151-160.

Vielma, J., Koskela, J., Ruohonen, K., Jokinen, I. \& Kettunen, J. 2003. Optimal diet composition for European whitefish (Coregonus lavaretus): Carbohydrate stress and immune parameter responses. Aquaculture 225(4): 3-16.

Wassef, E. \& Eisawy, A. 1985. Food and feeding habit, of wild and reared gilthead bream Sparus aurita (L.). Cybium 9: 233-242.

Weiss, D.J. \& Wardrop, K.J. 2011. Schalm's Veterinary Hematology. New York: John Wiley \& Sons.

Wilson, R. \& Taylor, E. 1993. The physiological responses of freshwater rainbow trout, Oncorhynchus mykiss, during acutely lethal copper exposure. Journal of Comparative Physiology B 163: 38-47.

Wise, D., Tomasso, J., Gatlin, D., Bai, S. \& Blazer, V. 1993. Effects of dietary selenium and vitamin $\mathrm{E}$ on red blood cell peroxidation, glutathione peroxidase activity, and macrophage superoxide anion production in channel catfish. Journal of Aquatic Animal Health 5: 177-182.
Wright, P., Leathwood, P. \& Plummer, D. 1972. Enzymes in rat urine: Alkaline phosphatase. Enzymologia 42(4): 317-327.

Ye, Y., Wang, Y. \& Shen, Z. 2006. National guide to clinical laboratory procedures. Nanjing: Southeast University Press. pp. 246-249.

Yuan, W., Li, X., Kangjian, Y., Zhong, W., Xiumei, S., Hongfeng, T. \& Xiping, L. 2005. Effect of beta-cypermethrin on GPT and GOT activities of crucian serum. Agricultural Science \& Technology 6(1): 20-23.

Yue, Y.R. \& Zhou, Q.C. 2008. Effect of replacing soybean meal with cottonseed meal on growth, feed utilization, and hematological indexes for juvenile hybrid tilapia, Oreochromis niloticus $\times$ O. aureus. Aquaculture 284: 185189.

Zar, J.H. 1984. Biostatistical Analysis. 2nd edition. USA: Prentice Hall.

Sabuj Kanti Mazumder \& Simon Kumar Das*

Centre for Ecosystem Management and Natural Resources

Faculty of Science and Technology

Universiti Kebangsaan Malaysia

43600 UKM Bangi Selangor, Darul Ehsan

Malaysia

Sveinung Fivelstad

Department of Biochemical Laboratory Sciences and Chemical Engineering

Western Norway University of Applied Sciences, Bergen

Norway

Mazlan Abd. Ghaffar

Institute of Oceanography and Environment

University Malaysia Terengganu

21030 Kuala Nerus, Terengganu Darul Iman

Malaysia

Simon Kumar Das*

Marine Ecosystem Research Center

Faculty of Science and Technology

Universiti Kebangsaan Malaysia

43600 UKM Bangi, Selangor Darul Ehsan

Malaysia

Sabuj Kanti Mazumder

Department of Genetics and Fish Breeding

Faculty of Fisheries

Bangabandhu Sheikh Mujibur Rahman Agricultural University

Gazipur-1706

Bangladesh

*Corresponding author; email: skdas_maa@yahoo.com

Received: 29 October 2018

Accepted: 14 June 2019 